\title{
DILEMATA SOCIÁLNÍCH PRACOVNÍKŮ S OHLEDEM NA PRÁCI S ROMSKÝM ETNIKEM
}

\begin{abstract}
Abstrakt
$\mathrm{V}$ tomto textu nejprve vymezíme dilemata a popíšeme proces jejich vzniku. Budeme se věnovat popisu dilemat $\mathrm{v}$ historii a to prostřednictvím šesti hodnotových a etických směrů. Nastíníme etická dilemata neboli problémy sociálních pracovníků tak, jak jsou pojímány v Etickém kodexu Společnosti sociálních pracovníků České republiky. V další části se budeme věnovat dilematům současné sociální práce. Zvlášt pak ve zkratce popíšeme dilema mezi právem a etikou. Celkem vymezíme osmnáct dilemat a ke každému uvedeme, jak se eventuálně mohou promítnout do práce s romským etnikem. Jedná o osobní zkušenosti autora a také o zkušenosti sociálních pracovníků. Také zde navrhneme možnosti, jak s těmito dilematy pracovat.
\end{abstract}

Klíčová slova: dilema, sociální práce, etický kodex, sociální pracovník, romské etnikum.

\section{Vymezení a vznik dilemat}

„Etické dilema je situace, kdy pracovník stojí před nezbytným a nevyhnutelným rozhodnutím (dvě nebo více možností), které mají srovnatelně nepř́ijemné nebo nepř́iznivé varianty řešení a zdá se, že přijatelné řešení v podstatě neexistuje (pracovník např. musí vybrat tzv. „menší zlo“ a nemůže se rozhodnutí vyhnout třeba tak, že by rozhodnutí přesunul na někoho jiného a na základě zkušeností ví, že optimální řešení neexistuje.“ (Sýkorová, 2008, s. 80) „Dilema je nutná (někdy obtížná) volba mezi dvěma vzájemně se vylučujícími možnostmi." (Musil, 2004, s. 36) Možnosti, mezi kterými se vybírá, bývají neslučitelné. Je nutné se rozhod- 
nout bud' pro jednu, nebo naopak pro druhou variantu. Někteří pracovníci se snaží výběr oddálit nebo se mu zcela vyhnout. Jestliže se jim to daří, začnou postup rutinně opakovat. Je možné, že dočasné vyhýbání selže a pak je nutné se opravdu rozhodnout. (Musil, 2004)

Když se práva a povinnosti sociálního pracovníka vzájemně doplňují, tak jdeo ideální situaci. V praxi se však často dostávají do konfliktu a to v souvislosti s dalš́ími povinnostmi sociálního pracovníka. Ten má povinnosti ke klientům, k profesi, zaměstnavateli, a ke společnosti. (Nečasová, 2001) Pokud se práva a povinnosti dostávají do konfliktu, jedná se o situaci, ve které se vyskytují dvěa více dilemat mezi kterými je pracovník nucen se rozhodovat.

Nečasová (2001) uvádí, že existují tři oblasti, ve kterých často dochází k dilematům:

- Oblast, která se týká práv a kvality života klienta.

- Oblast, vztahující se k obecnému blahu.

- Oblast, týkající se nerovnoprávnosti a strukturálního útlaku.

Etická dilemata podle Nečasové (2001), vznikají v situaci kdy:

- je zřejmé, jak by se měl sociální pracovník rozhodnout, ale toto rozhodnutí se mu príící,

- sociální pracovník stojí před více možnostmi rozhodnutí a neví jistě, které rozhodnutí bude vhodnější.

„Střet s obtížným rozhodnutím, který je výsledkem morální interpretace určitého konfliktu očekávání, může vyvolat nejistotu, která pracovníky přivede ke snaze znovu měnit jednou již „ujasněnou“ představu o povaze konfliktu očekávání. Celý proces může probíhat znovu a znovu, přičemž návraty $\mathrm{k}$ jednou již přijatým a později odmítnutým úvahám jsou běžné.“ (Musil, Nečasová, 2008, s. 92)

\section{Dilemata v historii}

Lze identifikovat šest hodnotových a etických směrů, které jsou v historickém pohledu patrné a které vykazují různý stupeň vytrvalosti. Jedná seo následující orientace, ve kterých je možné vidět dilemata vztahující se $\mathrm{k}$ dané orientaci:

1. Paternalistická orientace - tato perspektiva byla nejpopulárnější koncem 19. a začátkem 20. století. Sociální pracovníci se snažili vylepšit mravníprofil klientů, tak aby žili ctnostně a byli užiteční.

2. Orientace na sociálni spravedlnost - podle této perspektivy je závislost způsobena strukturální závadou v kulturním a ekonomickém životě, kteráprovází ty nejméně zvýhodněné. Tuto situaci může zlepšit změna, jejímž cílem je nastolení rovnosti př́ležitostí, redistribuce bohatství, nestigmatizujících př́ispěvků a služeb. 
3. Náboženská orientace - základní poslání profese má kořeny v historickém pojení sociální práce $s$ církví. Často jde o transformaci náboženského přesvědčení sociální pracovníka v smysluplnou sociální službu. Charitativní činnost může nap̌r. reprezentovat křestanskou lásku mezi jednotlivci a Bohem a mezi bližními.

4. Klinická orientace (orientace sloužící badatelským a vyučovacím úkolům a prevenci) - ve středu pozornosti jsou diskuze o klientově důvěre, způsobu komunikace, podávání pravdivých informací, klientovu souhlasu s postupem sociálního pracovníka, střetu zájmů apod. Jde především o ochranu a prospěch klienta.

5. Defenzivni orientace - jde především o ochranu sociálního pracovníka. Tomuto pojetí dominuje otázka odpovědnosti a problémy spojené s nebezpečím soudního sporu mezi pracovníkem a klientem.

6. Morálně neutrálni orientace - jejími stoupenci jsou ti sociální pracovníci, kteří praktikují spíše technický přístup k sociální práci." (Nečasová, 2001, s. 50-52) $\mathrm{V}$ př́ípadě každé výše vypsané orientace si můžeme doplnit možná dilemata, ke kterým mohlo docházet. $\mathrm{V}$ př́ípadě paternalistické orientace by se nejspíše jednalo o dilemata mezi zakázkou uživatele a zakázkou veřejné instituce, zájmem uživatele a veřejným zájmem, normativností a nenormativností, zasáhnout a nezasáhnout. $V$ př́padě orientace na sociální spravedlnost by se mohlo jednat o dilemata mezinormativností a nenormativností, zasáhnout a nezasáhnout, jednostranností a symetrií, procedurálním a situačním př́stupem. V př́padě náboženské orientace se může jednat o dilemata mezi formalizací a de-formalizací, profesionalizací a de-profesionalizací, monologem a dialogem. V př́padě klinické orientace se jedná o prŕmou orientaci na etická dilemata. V rámci této kategorie lze př́mo nalézt orientaci na práci téměř se všemi dilematy, která jsou zaměřená na ochranu klienta. Jde např́klad o dilemata mezimateriální a nemateriální pomocí, zasáhnout a nezasáhnout, pomoc a kontrola,a to ze strany klienta. $\mathrm{V}$ př́padě defenzivni orientace jde především o etická dilemata, která se zaměřují na samotného pracovníka. Např́íklad dilemata mezi formalizací a de-formalizací, zasáhnout a nezasáhnout, pomocí a kontrolou, mlčenlivostí a oznamovací povinností. V prrípadě morálně neutrální orientace se mohou vyskytovat dilemata mezi kvalitou a kvantitou, jednostranností a symetrií, procedurálním a situačním př́stupem, monologem a dialogem.

\section{Etická dilemata}

V této části textu se popíšeme vymezení etických problémů, které při výkonu sociální práce mohou nastat a to konkrétně podle Etického kodexu Společnosti sociálních pracovníků České republiky: 
A. Základní etické problémy jsou

- „kdy vstupovat či zasahovat do života občana a jeho rodiny, skupiny či obce (např. z hlediska prevence či sociální terapie společensky nežádoucí situace),

- kterým sociálním př́padům dát přednost a věnovat čas na dlouhodobé sociálně výchovné působení,

- kolik pomoci a péče poskytnout, aby stimulovaly klienta ke změně postojů a k odpovědnému jednání a nevedly $\mathrm{k}$ jejich zneužití,

- kdy přestat se sociální terapií a poskytováním služeb a dávek sociální pomoci.“ (Etický kodex Společnosti sociálních pracovníků ČR, 2006, s. 4)

B. Další problémové okruhy, vyžadující etické rozhodování, vyplývající z:

- konfliktu mezi zájmy sociálního pracovníka a zájmy klienta,

- konfliktu klienta s jiným občanem,

- konfliktu instituce či organizace a skupinou klientů,

- konfliktu mezi zájmy klientů a společností,

- konfliktu mezi zaměstnavatelem a sociálními pracovníky (zaměstnanci).

(Etický kodex Společnosti sociálních pracovníků ČR, 2006)

C. Sociální pracovník má ve své náplni roli pracovníka který klientům nabízí pomoc, ale současně je kontroluje. Tyto protichůdnéaspekty vyžadují vyjasnění kontrolní role sociálním pracovníkem. Je nutné zvážit přijatelnost této role z hlediska hodnot sociální práce.(Etický kodex Společnosti sociálních pracovníků ČR, 2006)

\section{Dilemata v současné sociální práci s romským etnikem}

Podle Navrátila (2001) se v sociální práci v 19. století, a zvláště pak ve 20. století, projevilo velké množství protichůdných snah a tendencí, které on sám nazývá „vývojová dilemata." Rád bych zde vyšel právě z Navrátila a popsal šest základních protichůdných tendencí, které ovlivňují výkon sociální práce. Dále se budu zabývat sedmi dilematy, která uvádí Musil (2004). On sám je označuje jako všední, které „vyvstávají, když pracovníci kvůli nepřízni pracovních podmínek nemohou s klienty jednat tak, jak by považovali za adekvátní. Do stejné situace se mohou dostat, pokud v daných pracovních podmínkách mohou uplatnit odlišné, stejně príijatelné, ale neslučitelné postupy." (Stachová, 2012, s. 20)

$\mathrm{Na}$ následujících řádcích definuji výše zmíněná dilemata sociálních pracovníků spolu s konkrétním promítnutím těchto dilemat do práce se specifickou skupinou klientů romského etnika. 


\section{Dilema mezi právem a etikou}

V této části jen krátce nastíním dilema mezi právem a etikou. Předem upozorňuji, že se nejedná o souhrnný text pojednávající o této problematice, ale pouze o úvod do problematiky s naznačením relevantních zdrojů a př́stupů $\mathrm{k}$ tomuto dilematu. (Janebová, 2010).

„Sociální pracovníci dbají na dodržování lidských práv u skupin a jednotlivců tak, jak jsou vyjádřeny v dokumentech relevantních pro praxi sociálního pracovníka, a to především ve Všeobecné deklaraci lidských práv, Chartě lidských práv Spojených národů a v Úmluvě o právech dítěte a dalších mezinárodních deklaracích a úmluvách. Dále se řídí Ústavou, listinou základních práv a svobod a dalšími zákony tohotostátu, které se od těchto dokumentů odvíjejí." (Etický kodex sociálních pracovníků, 2006, s. 1) „Sociální pracovník požaduje uznání toho, že je zodpovědný za své jednání vůči osobám, se kterými pracuje, vůči kolegům, zaměstnavatelům, profesní organizaci a vzhledem k zákonným ustanovením, a že tyto odpovědnosti mohou být ve vzájemném konfliktu." (Etický kodex sociálních pracovníků, 2006, s. 3) Z první citace vyplývá, že je profese sociální práce podřízena právu naproti tomu z druhécitace vyplývá, že je zde možnost uznání konfliktu, který vznikl mezi právem a etikou na základně individuální zodpovědnosti pracovníka. (Janebová, 2010) Právě v této situaci se projevuje rozpor, tedy kdy jednat podle prvního bodu etického kodexu a ř́ídit se právními předpisy a kdy naopak jednat podle druhého bodu kdy jednání může být v konfliktu se zákonnými ustanoveními.

Řešení toho typu dilematu navrhuje Janebová (2010) následovně. „Za prvé je potřebné zachovat si profesní nezávislost mezi klienty a společností. Za druhé mít na vědomí, že právo není totožné s morálkou a nezbavuje zodpovědnosti za etické rozhodování. Za třetí je nutné vytvořit si citlivost vůči opresivnímu působení právních norem, tedy „nemlčet“, měnit prostředí a zákony, aby se snižovala pravděpodobnost vzniku takovýchto konfliktů... A za čtvrté, když už takovýmto dilematům dojde,tak je řešit situačně (individuálně)..." (Janebová. 2010, s. 52-53)

Dalo by se říct, že optikou tohoto dilematu by se dalo dívat na následující dilemata,protože v některém z nich můžeme nalézt právě působení konfliktu mezi právem a etikou.

\section{Formalizace a de-formalizace}

V 19. století byla sociální práce z velké části poskytovaná z iniciativy soukromých a církevních organizací. Ve 20. století se sociální práce stává organizovanou, financovanou a centralizovanou státem. Formalizace znamená úplné převedení so- 
ciální práce pod veřejné, územněsprávní a státní instituce.Snaha o de-formalizaci vznikla jako odezva na otázky týkající se levnějšího řešení sociálních problémů. Kdy je sociální práce navrácena zpět k samotnému sociálnímu pracovníkovi, který má potřebné vzdělání a pomoc poskytujev přirozeném prostředí klienta. Jak formalizovaná, tak neformální sociální práce se vyvíjely obě zároveň a převaha jedné nad druhou je ovlivněna konkrétní politickou situací v té které zemi. V České republice je od 90. let 20. století možné sledovat jinou formu de-formalizace, a to rozvoj nestátního neziskovéhosektoru, kde je sociální práce poskytována na profesionální úrovni, ale také na občanské vzájemnosti a solidaritě. (Navrátil, 2001)

Promítnutí dilematu do romské problematiky: Jak již bylo výše zmíněno, pod formalizovanou sociální prací si můžeme představit sociální práci vykonávanou veřejnými, územněsprávními a státními institucemi (financovanou, organizovanou a centralizovanou státem), pro potřeby této práce budu dále používat souhrnné označení úřady. $\mathrm{V}$ otázce romské problematiky se můžeme zaměřit na to, jaké služby a v jakém rozsahu jsou Romům poskytovány prostřednictvím právě těchto úřadů a prostřednictvím nestátního neziskového sektoru. Nejspíše bychom došli k závěru, že těmto klientům jsou skrz úřady poskytovány stejné služby a prakticky ve stejnémrozsahu jako je to u klientů neromských. Nedá se tedy mluvit o nějaké speciálnípropracované struktuře služeb a pomoci, které by byly upraveny romským klientům přesně na míru. Naopak tomu je v rámci nestátního neziskového sektoru. Pracovníci neziskového sektoru jsou lépe připraveni na práci s těmito klienty, proškoleni a mnohokrát osobně do problematiky „zapáleni“, proto jsou s romskými klienty schopni pracovat na jiné úrovni a s jinou mírou zaujetí,nabízet služby, které jsou přesně vybrány pro tento typ klientů a často poskytovány v jeho přirozeném prostředí. (Srovnej: Mojžíšová, Urban, Kajanová, 2012)

\section{Profesionalizace a de-profesionalizace}

Snahu o profesionalizaci sociální práce můžeme vnímat jako tvorbu profesního etického systému, kontrolu, standardizovanost a vymezení okruhu kompetencí,vytvárení profesního statusu a postavení k ostatním profesím, nalézání novýchvztahů mezi sociálními pracovníky a klienty. De-profesionalizace naopak, má umožnit př́istup $\mathrm{k}$ sociální práci i laikům. Sociální práci tak mohou vykonávat přátelé, rodina, dobrovolníci, kteří jsou mnohdy schopni dosáhnout mnohem lepších výsledků. Naproti tomu profesionální intervence je součástí dané doby tím, že je racionální a orientovaná na praktický výsledek a proto přináśí mnoho výhod i přesto ale, je její účinnost někdy velmi nízká. (Navrátil, 2001) 
Promítnutí dilematu do romské problematiky: Dilema můžeme spatřovat $\mathrm{v}$ tom, zda by s romskými klienty měli v zařízení pracovat pouze sociální pracovníci odborně vyškolení se speciální vzděláním, průpravou, kurzy a dostatečnými kompetencemi, či zda bychom $\mathrm{v}$ rámci této problematiky měli nechat více prostoru pro zapojení samotných Romů, „aktivistü“ či „dobrovolníkủ“. Tito se snaží o zlepšení situace v komunitě tím, že se přidají do odborného týmu sociálních pracovnic a na řešení problémů klientů spolupracují. Velké výhody můžeme spatřovat v tom, že spolupracující pracovník z řad Romůmá velmi často neformální vazby s klienty a je tedy schopen s nimi lépe navázatspolupráci a mnohdy dosáhnout kvalitnějších a rychlejších výsledků než tým velice kvalifikovaných sociálních pracovnic s odpovídajícími kompetencemi. Cílem není upřednostnit jednu nebo druhou skupinu pracovníků, $v$ nejlepším př́padě a také v nejlepším zájmu klienta je, aby s ním spolupracoval tým, který seskládá z pracovníků jak profesionálů, tak i pracovníků z řad klientů samotných a společně pracovali na stejném zájmu. (Srovnej: Ondrejkovič, 2010)

\section{Normativnost a nenormativnost}

Sociální práce je profese, která pomáhá lidem stojícím mimo většinovou společnost, přizpůsobit se této společnosti. Sociální práce tedy zaujímá normativní funkci. V 60. letech se ale objevila kritika této normativní funkce, která vycházela od marxistů. Zpochybnila pojetí sociální práce jako povinnosti. To znejistilo celé pojetí sociální práce jako profese, která pojímá sociální problémy jako vyřešitelné nesnáze konkrétních osob a mění je na boj, který je zaměřen proti majoritní společnosti. Spolu s tímto se vynořuje základní problém a to rozporuplnost mezi etnocentrismem a partnerstvím. „Etnocentrismus je přístup k jiným etnickým skupinám založený na nereflektovaném preferování hodnot a postojů typických pro etnickou skupinu posuzujícího." (Matoušek, 2008, s. 64) Etnocentrismus je v tomto př́ipadě konkrétněji chápán jako př́stup sociálních pracovníkủ ke klientům, který je ovlivněn hodnotami a normami dané skupiny či celé společnosti do které sociální pracovník př́śluší. Autoři si začínají klást otázky, zdali je možné klientovi efektivně pomoci z postavení člena etablované majoritní společnosti?

Partnerství naopak znamená podporu klienta bez ohledu na normy a hodnoty panující v dané společnosti. (Navrátil, 2001)

Promítnutí dilematu do romské problematiky: Toto dilema se projevuje při sociální práci $s$ romskými klienty a značně ji ovlivňuje. $\mathrm{V}$ př́ípadě, že ke klientovi pracovnice přistupuje ze své pozice, jako člena majoritní společnosti, není většinou schopna nenormativního př́stupu. Romští klienti pochází z jiné skupiny než my, 
členové majority a proto i jejich normy a hodnoty jsou jiné, než normy a hodnoty členů majority. $\mathrm{V}$ př́padě, že pracovnice tyto rozdíly nedokáže reflektovat a pracovat $s$ nimi, může docházet $\mathrm{k}$ velkým chybám při práci s romskými klienty. Např́íklad patriarchální pojetí rodiny, či vztah romských rodin mezi sebou vně i uvnitř, př́stup ke škole či pojímání nevěry mezi manžely je značně odlišné, proto by bylo zapotřebí, aby se pracovnice $\mathrm{v}$ rámci práce $s$ touto skupinou nesnažila Romy „dostat do normy", nutně a za každou cenu jim vnucovala hodnoty uznávané většinovou společností a vyhnula se celkovému etnocentrickému př́stupu. Pro vyřešení, nebo alespoň zmírnění tohoto dilematu považuji za nutné, aby pracovnice $\mathrm{k}$ těmto klientům přistupovala skrz jejich odlišnosti a snažila se na jejich situaci nahlížet z pozice klienta, a toho jaké má postavení v rodině a komunitě. (Srovnej: Kappl, 2012, Vojtko, 2008)

\section{Polyvalence a specializace}

Dilema souvisí s organizací sociálních služeb. Polyvalenci si můžeme vyložit jako situaci, kdy sociální pracovník poskytuje služby klientům v nejrůznějších situacích (nespecializuje se pouze na děti a mladistvé či seniory nebo postižené, ale zaštítí služby pro všechny druhy klientů). Naproti tomu specializace znamenáprofesionální působení na určitý druh klientů s určitým sociálním problémem.

Promítnutí dilematu do romské problematiky: $\mathrm{V}$ př́ípadě tohoto dilematu bychom se mohli zaměrit na to, jak jsou organizovány sociální služby pro Romy. A to konkrétně na př́pad, kdy v jedné romské rodině spolupracuje více organizací/poskytovatelů sociálních služeb a ona tak využívá služby a pomoc od více než jen jednoho sociálního pracovníka. Pracovníci k nídocházející se snaží pomoci s řešením celkové situace. Většinou nepřicházejí, aby řešili jen jeden určitý problém. Např́íklad do rodiny s největší pravděpodobnostínebude docházet pracovnice, aby řešila pouze finanční problematiku či pracovnice nabízející volnočasové aktivy a doučování pro děti bez zájmu o další problémy. Problémy klientů bychom měli vždy brát komplexně, protože jsou často provázané a jeden nejde vyřešit bez pomoci a řešení problému druhého. $V$ prrípadě, že se v rodině vyskytuje více pracovníkủ, kteří s rodinou spolupracují, mělo by s ohledem na zájmy všech, dojít k jakémusi propojení služeb od obou organizací a to alespoň na úrovni poskytování informací ohledně aktuálních potřeb a problémů $\mathrm{v}$ rodině, včetně jejich následného řešení danými pracovníky.Pracovníci z různých organizací by měli spíše spolupracovat než se navzájem snažit být pro klienta tím lepším. $V$ tomto př́padě jde, podle mého názoru, hlavně o spolupráci a vymezení kompetencí daných pracovnic a to s ohledem na zájmy klienta. (Srovnej: Šotola, 2012) 


\section{Sociální práce jako věda a umění}

Sociální práce je často považována za jistý druh „umění " př̀i kterém je potřeba zvládat velké množství dovedností, které se mimo jiné vztahuje k porozumění potřebám druhých i schopnosti nabídnout pomoc tak, aby na ni člověk nadále nebyl závislý a aby byl schopný si příště pomoci sám. Sociální práce je ale často považována i za „vědu“ a to protože obsahuje spoustu teorií a vytváŕí nové tak, aby vysvětlily, proč vznikají sociální problémy a jak by se měly řešit. (Navrátil, 2001)

Promítnutí dilematu do romské problematiky: Někteří autoři tvrdí, že pro výkon profese sociálních pracovníků musí mít člověk určité předpoklady či snad talent. Tuto teorii bychom mohli rozvinout zvláště v př́padě práce $s$ romskými klienty. Ne každý sociální pracovník cítí, že by jeho cílovou skupinou mohli být právě Romové. Proto za vědu v tomto dilematu $s$ ohledem na romské klienty považuji schopnost, vybrat si z nabízených postupů, př́ístupů, teorií a metodik právě takové, které budou vhodné pro práci s tímto typem klientů a v prrípadě že nejsou vhodné, mohou vést $\mathrm{k}$ vytvoření zcela nových. $\mathrm{Na}$ druhou stranu za umění by se $\mathrm{v}$ tomto př́padě dal považovat určitý předpoklad, schopnost spolupráce $s$ odlišným etnikem. Proto bych se výlučně nesnažila vybrat mezi jedním nebo druhým a snažila se oba pohledy spojita nalézt to nejvhodnějšśi.(Srovnej: Macková, 2013)

\section{Pomoc a kontrola}

Od dilematu normativnosti do značné míry vychází i dilema mezi pomocí a kontrolou. Je zde do značné míry protichůdné pojetí oboru, kdy jedna část sociálních pracovníků považuje za svůj cíl sociální práce pomáhat klientům, naopak druhá část sociálních pracovníků za cíl sociální práce považuje sociální kontrolu. (Navrátil, 2001) Pomoc je „akt, při kterém jednotlivec nebo skupina něco poskytují jinému jednotlivci nebo skupině, přičemž adresát pomoci to, co je mu poskytnuto, využívá k řešení svého problému." (Matoušek, 2008, s. 150) Naproti tomu kontrola je „soubor formálních i neformálních postupů, kterými společnost vyvijí na jedince tlak, aby se choval v souladu s normami. Cílem je zajištění řádu a stability.“ (Matoušek, 2008, s. 209) „Cokoliv co pracovník v rámci své profese udělá, patří do jedné, nebo druhé kategorie: bud' klientovi pomáhá, nebo jej kontroluje." (Úlehla, 2005, s. 20) Obojí je považováno za profesionální způsob práce, obojí je potřebné a vyskytující se při rozhovoru s klientem. Úlehla (2005) uvádí, že aby se dalo mluvit o pomoci, musí být chápána jako výsledek spolupráce s klientem. Podle Laana (1998) se sociální pracovníci musí s tímto dilematem smírit. Je potřeba, aby vykonávali jak pomoc, tak kontrolu. 
Promítnutí dilematu do romské problematiky: Romové jsou často považováni za nespolehlivé a to nejen z důvodu, že mohou být negramotní, nerozumí úplně dobře česky či dokonce $\mathrm{v}$ některých případech nemusí ani umět hodiny a nedostaví se tak na schůzku včas, ale může to býtzpůsobeno také tím, že nemají denní režim, protože často nenavštěvují pravidelně zaměstnání. $Z$ tohoto důvodu může mít většina pracovnic tendenci $\mathrm{k}$ nim přistupovat $\mathrm{z}$ pozice vykonávající kontrolu. $\mathrm{V}$ mnoha př́padech mají tito klienti snahu řešit až akutní problémy a na dlouhodobé spolupráci se nechtějí podílet. $V$ tomto prrípadě se pro pracovnice může zdát jako jediné východisko, jak s klientem dosáhnout alespoň nějakých výsledků to, že nad nimi budou stát jako dozor. Často je v takových situacích vhodnější rozhodovat se mezi tím zda situaci nechat být (nechat tedy plně na klientovi, o pomoc nepožádal, čili nemá zakázku a sám pracovník nevidí důvod proč provádět kontrolu), anebo nabízet pomoc stále(snažit se zakázku s klientem hledat).Toto dilema souvisí s dilematy jednostrannost a symetrie, monolog a dialog. (Srovnej: Janebová 2012,Ševčíková, 2008)

\section{Zasáhnout a nezasáhnout}

„Sociální pracovníci nejsou v jednoznačné situaci ani v otázce načasování jejich př́ípadné intervence. Často si nemohou být jistí, jestli nereagují pouze na „falešný poplach“" a nezasahují v situaci, kdy jejich zásah není třeba a napáchá více škody než užitku. $\mathrm{Na}$ druhou stranu se snaží vyhnout situaci, kdy by jejich zásah přišel pro klienta př́liš̌ pozdě, nezasáhnutí z nedbalosti." (Kř́čková, 2011, s. 27) Pracovník by tedy měl uvážlivě zvážit každý jeden jediný případ, aby nedošlo ani $\mathrm{k}$ jedné z chyb a k tomu mu poslouží sada tř́i kritérií. První kritérium komplexnosti, kde se nacházejí tři světy - objektivní svět (kde pracovník zkoumá,jestli klient ví, jaká jsou fakta situace), normativní svět (jestli klient dokáže posoudit, jaká by situace měla být za normálních okolností), subjektivní svět (neboli důvěra klienta v pracovníka). Druhé kritérium dialogu, zkoumají se tři kompetence - instrumentální kompetence (schopnost popsat fakta), sociální kompetence (popsat problém z hlediska normativity), expresivní kompetence (schopnost pracovníka a klienta spolupracovat). Třetí kritérium metodické, pracovník si klade otázku, jestli vyčerpal možnost využití všech metod sociální práce při řešení daného př́ípadu s klientem. (Laan, 1998)

Promítnutí dilematu do romské problematiky: Velmi často si pod tímto dilematem můžeme představit jednání o péči o dítě v rodině. $V$ tomto př́padě se velice projevují normy a hodnoty společnosti proti normám a hodnotám romské menšiny a proto se pracovnice velice často a velice těžko rozhodují, kdy se jedná o jiný 
způsob péče o dítě, který vychází z jiné kultury a kdy se jedná o samotné zanedbávání a je nutné zasáhnout. $V$ př́padě, že se pracovnice snaží s rodinou pracovat na zlepšení situace dítěte $\mathrm{v}$ rodině a rodina nespolupracuje tak, jak by měla, bylo by teoreticky možné, po konzultaci s ostatními odborníky, a vysvětlení s rodinou, zasáhnout i přes nesouhlas samotné rodiny, to se však nejspiše stává jen ve velice krajních př́padech. (Srovnej: Janebová, 2012)

\section{Materiální a nemateriální pomoc}

Laan (1998) vymezuje materiální pomoc jako dávkovou (hospodářskou) a nemateriální jako poradenskou (výchovnou). Dilema spočívá v tom, zda má pracovník upřednostnit př́jmy - dát klientovi peníze (dávky), nebo zda ho má směrovat $\mathrm{k}$ metodickému vyučování jak s penězi hospodařit. $\mathrm{S}$ tím se váže druhé dilema a to jestli by se měla materiální pomoc poskytovat odděleně od nemateriální či pospolu. Spolu s tímto se objevují dvě chyby, kterých se pracovníci dopouštějí a to psychologizace a ekonomizace. Psychologizace je prŕlišné zaměření na nemateriální pomoc. Ekonomizace je naopak př́lišné zaměření na materiální pomoc. Pokud má klient velmi nízké př́ímy, kdy téměř nemůže zvládat svoje existenční podmínky, tak se doporučuje začít $s$ materiální pomocí a poté navázat pomoci nemateriální. Jestliže má klient př́ijmy dostačující, je nutné naučit ho s nimi nejdříve hospodařit, proto se začne nemateriální pomocí, ke které se přidá v př́ípadě potřeby pomoc materiální. (Laan, 1998)

Promítnutí dilematu do romské problematiky: Velice silně se toto dilema projevuje v zařízeních, nebo na úřadech, které poskytují jak materiální tak nemateriální

pomoc. Často se může stát, že si klienti přijdou pouze pro potraviny nebo oblečení a při konzultaci, která je součástí, ale nejsou aktivní či se jí vủbec nechtějí účastnit. Pracovnice se tak často ptají samy sebe jak s tímto problémem pracovat. Mnohdy se jako řešení zdá nastavení hranic a podmínek, při kterých je možné čerpat pomoc materiální, aby byli klienti předem obeznámeni a nesnažili se zařízení využít jen po této stránce. Toto dilema je velice problematické a to hlavně proto, že Romové danou situaci vnímají značně odlišně od reality. Proto se mnohdy na pracovnice zlobí, pokud jim nechtějí poskytnou to, na co mají podle nich nárok, nejsou ale už schopni pochopit, že jejich nárok je vázán určitou povinností. Je potřeba si v tomto zjednat pořádek, vyjasnit si situaci, být neústupní a dodržovat pokyny na pracovišti, jelikož pokud se pracovnice jednou podvolí a udělá výjimku, může si být jistá, že to nebude naposledy, kdy o to bude žádána. Takové neposkytnutí toho, na co mají klienti nárok, může vyústit až v napadání jak fyzické, tak slovní. (Srovnej: Květenská, 2008, Kasanová, 2008) 


\section{Komplexní a zjednodušené cíle}

Dilema je způsobeno tím, že sociální práce má nejasné cíle, což je způsobeno morálním zdůvodňováním a hodnocením poskytovaných služeb a všeobecnými cíli sociální práce, které nejsou konkrétní právě proto, aby mohly obsáhnout co nejširšsí sociální skupinu klientů. V důsledku širokých a všeobecných cílů se často projevují nejasnosti ohledně metodik a aplikačních předpisů $\mathrm{k}$ jednotlivým cílům. Potíž nastává, pokud jsou různá očekávání zainteresovaných subjektů - tedy cílklienta je jiný, než cíl jaký by si pro něj představovala veřejnost nebo je cíl klienta jiný než je cíl organizace. Pracovníkům v této situaci nezbývá nic jiného, než si cíle konkretizovat a vybrat ty, které lze vzájemně sloučit. Vytvárejí si tak vlastní pojetí cílů, které pokud je hromadné, můžeme ho nazývat ideologií organizace.(Musil, 2004)

Promítnutí dilematu do romské problematiky: Zvláště při práci s romskými klienty je vhodné stanovovat si menší, dílčí cíle - krůčky, které klienta povedou a zároveň ho budou motivovat $\mathrm{k}$ dosažení cíle dlouhodobého. Cíle by si neměly konkurovat, protože tím by došlo k nesouladu. $S$ touto cílovou skupinou může být velice těžké stanovovat si dlouhodobé cíle, protože jsou většinou orientováni na konkrétní okamžik, mnohdy nejsou schopni vidět provázanost mezi krátkodobým a dlouhodobým cílem a ztrácí motivaci, protože se jim splnění cíle zdá v nedohlednu. V rámci efektivní práce s touto skupinou většina pracovnic doporučuje volit spíše cíle zjednodušené (krátkodobé), které jsou pro tuto skupinu odpovídající, co se týče schopnosti plně se soustředit na změnu a dosažení cíle a věnovat pozornost konkrétnímu jednomu zájmu. Po splnění krátkodobého cíle jevhodné přejít na další a tak si dlouhodobý rozdělit jak v jednotlivé kroky. (Srovnej: Lehoczká, 2010)

\section{Množství klientů a kvalita služeb}

K dilematu dochází, pokud se na organizaci obrátí více klientů než kolik má organizace kapacitu zvládnout. Můžeme tedy jinými slovy mluvit o dilematu mezi kvalitou a kvantitou poskytovaných služeb. $S$ vyšším počtem klientů se snižuje čas, energie a pozornost, kterou je schopný pracovník jednotlivému klientovi věnovat. Tím dochází ke snížení kvality služeb, které je schopen klientovi poskytnout. Pracovník tak stojí před rozhodnutím, zda poskytovat alespoň částečnou službu všem klientům, anebo se zaměřit na menši počet klientů, ale poskytovat jim službu stoprocentní. (Musil, 2004)

Promítnutí dilematu do romské problematiky: Toto dilema bychom si mohli představit jako snahu pracovnice, při práci s romskými klienty, dodržet stanovenou dobu, kterou na klienta má vyhrazenou, což často nebývá možné z důvodu velkého 
množství klientů. Proto i přesto, že by danému klientovi prodloužení konzultace pomohlo, není mu to poskytnuto, nejsou tedy vyřešeny všechny problémy, které by bylo potřeba vyřřšit, což se pochopitelně projevuje na kvalitě situace klienta a poskytované pomoci. Klient tedy musí se svými problémy počkat do př́ístí konzultace, protože na řadě je další čekající klient. $\mathrm{V}$ případě romských rodin je toto velice komplikované, protože vydá-li se pracovnice do romské lokality a setká-li se $s$ rodinou, většinou se na pracovnici začínají s problémy obracet všichni, kteří jsou právě zúčastnění. Pracovnice se pak velice složitě v situaci orientuje a formuluje si zakázky od všech zúčastněných. Mnohdy tak stráví třeba přes polovinu času jen tím, že je potřeba ujasnit si co kdo potřebuje. V důsledku toho, se nestihnou věnovat žádnému z př́padů dostatečně, a protože čas uplynul, musí se pracovnice $s$ rodinou rozloučit $s$ př́islíbením, že přrišsě naváží tam, kde přestali. (Srovnej: Holasová, 2010)

\section{Neutralita a favoritismus}

Dilema pojednává o př́istupu sociálního pracovníka, který má potřebu klienty rozlišovat na „oblíbenéc a „ty ostatni“. K takovému rozlišování může dojít z důvodu individuálního př́istupu, který se snaží pracovník prosazovat, potřebě pomoci bližnímu za každou cenu, nebo snahy o uspokojení z dosaženého výsledku - tedy pracovník si ke spolupráci vybere klienta u kterého je větší pravděpodobnost, že snáze a rychleji dojde k dohodnutému cíli nebo klienta, který je mu osobně sympatičtější či mají jisté znaky společné. Pracovník na základně individuálního př́istupu musí rozlišovat mezi klienty s ohledem na jejich jednotlivé potřeby, tím se může stát, že by s určitým typem klientů mohl sympatizovat a s určitým typem ne. Dojde tedy $\mathrm{k}$ tomu, že bude určité klienty upřednostňovat, nebude tedy zaujímat neutrální a stejný postoj ke všem svým klientům. Na nerovný postoj sociálních pracovníků ke klientům mohou mít také vliv předsudky a stereotypy. (Musil, 2004) Předsudek je „...emocionálně silně zabarvený úsudek o druhých osobách, skupinách nebo některých záležitostech, který je možno jen obtížně změnit na základě nových zkušeností a informací. Jde o druh stereotypu." (Jandourek, 2007, s. 198)

Promítnutí dilematu do romské problematiky: $\mathrm{V}$ rámci romské problematiky se nerovný př́stup může projevit až v diskriminující chování eventuálně v rasovou nesnášenlivost. Předpokládám ale, že $s$ tím pracovníci poskytující služby romským klientům problém nemají a proto se zaměřím spíš na upřednostňování klienta mezi ostatními klienty. At́ už se jedná o romského klienta či klienta jiného původu, je velice důležité, aby $\mathrm{k}$ němu pracovnice přistupovala profesionálně, to znamená, snažila se o rovný př́istup $\mathrm{k}$ němu jako $\mathrm{k}$ ostatním klientům a v př́ípadě, že má vý- 
hrady k rovnému př́ístupu (odvíjející se od jakýchkoliv faktů) nemělo by docházet k extrémně jednostrannému př́stupu (a to jak na stranu pozitivní - tedy preference klienta, tak na stranu negativní - tedy nezájem či zanedbávání klienta). Pokud se pracovnice ve svém jednání setká s jedním z těchto vyhraněných príistupů ke klientovi, měla by požádat o převedení klienta k jiné pracovnici. (Srovnej: Vlachovičová - Mihalová, Csámpai, 2010)

\section{Jednostrannost a symetrie ve vztahu s klientem}

Dilema mezi tím, zda nechat rozhodovat klienta jaký cíl si zvolí a jakou cestu k cíli si zvolí, či zda-li by ho měl pracovník navádět a usměrňovat podle toho co sám považuje za správnou a nejlepší cestu k onomu cíli, či dokonce za samotný cíl. S tímto dilematem souvisí i uplatňování moci ze strany sociálního pracovníka. (Musil, 2004) V tomto dilematu se odráží, to jak sociální pracovník vnímá klienty. Pokud je vnímá jako subjekty, které si za své problémy mohou samy či naopak jako oběti nespravedlivého okolí, nejspíše se mu nepodaří dojít ke kladné interakci mezi klientem a jeho sociálním okolím, protože se soustředují bud’ na umravňování, nebo ochranu klienta. Jak s tímto dilematem pracovat? Pracovníci užívají tedy přirozené autority ve prospěch klienta, ale v některých prrípadech také autority přidělené, aby klienta trošku popostrčili tam, kam očekává společnost, že se klient po intervenci posune." (Kříčková, 2011, s. 25)

Promítnutí dilematu do romské problematiky: Toto dilema souvisí s dilematy pomoc a kontrola, monolog a dialog, proto bych zde na ně ráda odkázal. $V$ př́padě práce $s$ romskými klienty se mnohdy setkáváme s nejednoznačnými zakázkami a proto i přesto, že klient pracovníka s určitým problémem vyhledá, nemusí být zakázka $\mathrm{v}$ plné míre stanovena jen tak, jak si jí klient zvolil, ale naopak se často stává, že pokud pracovník už s danou rodinou začne pracovat, věnuje se i jiným problémům, na které upozorňuje a které má snahu řešit i přesto, že s nimi klient prvotně za pracovníkem neprrišel či je dokonce sám za problém nepovažoval. $V$ tomto př́padě tedy pracovník působí na klienta jednostranně. $V$ prvním př́padě se jednalo o symetrii ve vztahu mezi pracovníkem a klientem, která je i v rámci práce $s$ romskými klienty velmi důležitá a hraje velkou roli. (Srovnej: Selická, 2010, Musil, 2008)

\section{Procedurální a situační přístup}

Procedurální přístup je př́stup, kdy pracovníci aplikují na rozličné problémy klientů předem připravené postupy řešení. Situační přístup naopak zohledňuje každou 
jedinečnou situaci individuálního klienta a hledá proto př́stup, který by zohledňoval všechny okolnosti daného klienta. Řešením je soustředit se na zájem pracovníka, zájem klienta a legislativní nařízení. (Musil, 2004) V sociální práci můžeme nalézt tři prrístupy sociálních pracovníků, jedná se o typ profesionální, administrativní a filantropický. Tyto „mohou představovat tři myšlenkové orientační body, o něž se s různou intenzitou a různými způsoby opírají představy různých jedinců a skupin. Ti z nich vybírají dílčí myšlenky,propojují je a tímto způsobem vytvářejí různé kombinace." (Musil, 2008, s. 64)

Promítnutí dilematu do romské problematiky: U klientů romského původu se setkáváme nejčastěji s řešením naléhavých a komplikovaných problémů, proto by se dalo předpokládat, že by pracovnice pracující s touto skupinou klientů měly být spíše schopné a častěji uplatňovat situační př́stup. Tento prrístup je častěji preferovaný ze strany pracovnic neziskové sféry oproti veřejnému sektoru, kde jsou př́sně daná pravidla a postupy, kde se pracovnice často nemohou odklonit od předem připraveného - procedurálního př́stupu, což mnohdy pro tyto klienty nemusí být zcela vhodné. (Srovnej: Stachoň, 2012)

\section{Dilema mezi monologem a dialogem}

Pokud pracovník s klientem jedná z pozice nadřazenosti, vede s klientem monolog, naopak pokud pracovník jedná s klientem rovnocenně, vede $s$ klientem dialog. Tedy, je schopný klienta považovat za experta na jeho situaci, zahrnuje ho do jednání a považuje ho za objekt zájmu. Monolog vždy nemusí být asymetrický, protože i díky němu může dojít mezi klientem a pracovníkem k porozumění, naopak dialog nemusí být vždy symetrický, protože může být nástrojem skrytého ovládání, v prrípadě pokud klient nemá plně otevřený prostor pro vlastní vyjádření. (Laan, 1998)

Promítnutí dilematu do romské problematiky: Toto dilema souvisí s dilematy pomoc a kontrola, jednostrannost a symetrie, proto bych na ně zde rád odkázal. Při práci s romskými klienty je zvláště nutné pracovat pomocí dialogu. Pokud pracovník s těmito klienty nejedná rovnocenně, většinou dojde k zablokování ze strany klientů a $\mathrm{k}$ přerušení spolupráce. Zvlášṫ $\mathrm{v}$ př́padě práce s romskými klienty je prospěšnější se vyhnout celkovému direktivnímu přístupu, je potřeba klienty zahrnovat plně do spolupráce a tím je více zplnomocňovat. Monolog svádí jednat tak, jak považuje za vhodné pracovník, a ne tak, jak si přeje sám klient. Dochází tak k jednostrannosti. (Srovnej: Selická, 2010, Kappl, 2010) 


\section{Oznamovací, informační povinnost a mlčenlivost, důvěrnost informací}

Oznamovací povinnost je potřeba vnímat tak, jak je uvedena v Trestním zákoníku č. 40/2009 Sb. v platném znění. Informační povinnost vychází ze Zákona o sociálně právní ochraně dětí č. 359/1999 Sb. v platném znění. Trestní zákoník skrze dva klíčové paragrafy vymezuje situace, kdy se samo neoznámení trestného činu stává trestným činem. Jde o $\$ 367$ „nepřekažení trestného činu“, který se vztahuje na trestné činy zrovna páchané nebo připravované. „Překazit trestný čin lze i jeho včasným oznámením státnímu zástupci nebo policejnímu orgánu...." (Trestní zákoník, 2009, $\$ 367$, odstavec 3) Druhým paragrafem je $\$ 368$ „neoznámení trestného činu“, kdy jde o čin, který se už stal. Ze Zákona o sociálně-právní ochraně dětí č. 359/1999 Sb. v platném znění vyplývá „povinnost sdělování informací.“ (Zákon o sociálně-právní ochraně dětí, 1999, $\$ 51$, odstavec 1 ). Povinnosti zachovávat mlčenlivost podle zvláštního právního předpisu se nelze dovolávat, jestliže mají být sděleny údaje o podezření z týrání, zneužívání dítěte nebo ze zanedbávání péče o něj.“ (Zákon o sociálně-právní ochraně dětí, 1999, $\$ 53$, odstavec 1$)$. Naproti tomu mlčenlivost a důvěrnost informací jsou velice důležité pro oblast sociální práce, které jsou vymezeny Zákonem o sociálních službách č. 108/2006 Sb. v platném znění,Na druhou stranu se povinnosti mlčenlivosti nelze dovolávat, jestliže mají být sděleny údaje o podezření z týrání, zneužívání dítěte nebo ze zanedbávání péče o něj. (Janebová, 2010, s. 43)

Promítnutí dilematu do romské problematiky: V rámci tohoto dilematu se nejčastěji vyskytují rozpory pracovnic ohledně zákonných a nezákonných aktivit svých klientů. Často se stává, že i přesto že pracovnice ví, že daný čin hlásit nemusí, potýkají se $s$ možností ohlásit a předejít zhoršení situace či právě naopak. Romové si často k pracovnicím vytvárejí určitý vztah po delší dobu, zprvu jim mnohdy nevěrí a jen čekají až je pracovníci „podrazí. Může tedy i delší dobu trvat než s pracovnicemi opravdu začnou spolupracovat na problému. $V$ rámci vybudované důvěry a vztahu mezi klientem a pracovníkem se $\mathrm{v}$ tomto př́padě mủže stát, že se klienti začnou svěřovat $s$ věcmi, které by pracovník neměl nechat bez povšimnutí. Klient by na to měl být vždy upozorněn a mělo by se pracovat na pochopení situace s ohledem na legislativní normy i vztah a důvěru mezi spolupracujícími stranami. (Srovnej: Janebová, 2019)

\section{Zakázka uživatele a zakázka veřejné instituce}

Dilema vychází z postavení sociálního pracovníka, který má být prostředníkem mezi klientem a veřejnou institucí. Zájmy a cíle klienta však mohou být v rozporu. " (Nedělníková, 2008, s. 380) 
Promítnutí dilematu do romské problematiky: $\mathrm{V}$ př́ípadě tohoto dilematu si můžeme představit např́k lad snahu organizace podporovat klienty $\mathrm{v}$ tom, aby si našli zaměstnání či splatili své dluhy nebo si další půjčky neuzavírali. Pracovníci, kteří v organizaci pracují, považují takové cíle za správné, protože jako členové majoritní společnosti a zástupci veřejného zájmu jsou si vědomi, že jedině tak může dojít k opravdovému zlepšení situace a zplnomocnění klienta. Naproti tomu cíle samotného klienta, který nemá snahu pracovat na nalezení zaměstnání, nechce splatit své dluhy a jedinýmmožným př́ímem pro něj jsou další a další půjčky, které si dále sjednává, jsou považovány jím samotným za správné, nehledě na to, co považuje za správné pracovník či samotná společnost. Právě v této situaci se projevuje rozpor mezi zakázkou klienta a zakázkou organizace.(Srovnej: Sveřepa, 2010)

\section{Zájem uživatele a veřejný zájem}

„Dilema vychází z možného protikladu zájmů klienta a společnosti, zejména při takové činnosti klienta, která podléhá ohlašovací povinnosti nebo ji lze chápat jako protispolečenskou.“ (Nedělníková, 2008, s. 381)

Promítnutí dilematu do romské problematiky: Za prríklad tohoto dilematu můžeme považovat situaci, kdy se klient pracovnici zmíní, že pracuje „načerno“. Veřejným zájmem přece je, aby všichni jednali v souladu se zákonem, a práce „načerno“ je protispolečenská. Proto by pracovnice takové jednání klientovi měla rozmluvit. Na druhou stranu se ale často stává, že když už má romský klient opravdu zájem na tom pracovat, tak se často setkává s odmítáním ze strany zaměstnavatelů a proto mu mnohdy ani nezbude jiná možnost než si tento druh práce vybrat či naopak nepracovat vưbec.

\section{Místo závěru - Možnost jak pracovat s dilematy}

Cílem této podkapitoly není úplné vymezení možností, jak pracovat $s$ dilematy, ale pouze krátce vymezit, jednu z možností. Na pomoc si vezmeme etické zásady práce s klienty:

1. Kritičnost k oboru i k vlastní osobě, schopnost sebereflexe - pracovník by měl pracovat $\mathrm{v}$ rámci svých možností a dbát na bezpečí klienta, které by se měl snažit neohrožovat.

2. Obětavost pod kontrolou - pracovník by neměl potlačovat svoje potřeby a věnovat se pouze klientovi na úkor sebe. 
3. Odborný zájem versus osobní zájem klienta - se mohou dostat do konfliktu, pracovník by neměl upřednostňovat své zájmy nad zájmy a potřeby klienta.

4. Zabezpečení citových potřeb profesionála a ochrana klienta - pracovník by měl být schopen rozpoznat svoje motivy pro výběr profese i při jednotlivých rozhodnutích a dále pocity a city, které má směrem keklientovi.

5. Kolegialita a otevřenost - spolupráce, kolegiální vztahy, prostor pro sdělení obav a nesouhlasu.

6. Respekt $\mathrm{k}$ důvěrnosti informací a údajů - respektování mlčenlivosti a přání klienta.

Všechny tyto body se prolínají a spolupůsobí s osobností každého pracovníka, $s$ jeho osobností, zkušenostmi, hodnotovým žebřičkem, rodinným zázemím a celkovou historií. Je potřeba vzít na vědomí, že ,jaký vztah má pracovník sám k sobě, takový mívá i ke klientům. Jaké vztahy mají pracovníci mezi sebou, takové mívají ke klientům." (Úlehla, 2005, s. 113)

„Sociální pracovník by se měl snažit svoji odpovědnost i způsoby řešení problémů na různých úrovních udržovat v rovnováze." (Nečasová, 2001, s. 7) Př́i práci s dilematy je potřeba neustálého zkoumání jak si v které situaci stojím, jaké jsou mé možnosti a hranice, kam je mohu posunout a $\mathrm{v}$ čem se mohu zlepšovat. Nutně se musíme ohližet na kompetence a jejich rozsah at už ze strany klienta, tak i samotného sociálního pracovníka. Je dobré brát neustále v potaz přání klienta a možnosti pracovníka a prostředky organizace, jedině tak je možné se v rámci dilemat rozhodovat $s$ ohledem na konkrétní situaci a zájem zainteresovaných subjektů. Jak sám podotýká ve své knize Musil (2006), některé dilematické situaci jsou neslučitelné a rozhodování mezi nimi bývá velice obtí̌né.

\section{Literatura}

Etický kodex Společnosti sociálních pracovníků ČR. [online]. 2006, [cit. 20. 10. 2014]. Dostupné z: http://socialnipracovnici.cz/public/upload/image/eticky_ kodex_sspcr.pdf

Holasová V. (2010). Manažerismus v sociální práci. In M. Smutek, W. F. Seibel, Z. Truhláŕová, (eds.) Rizika sociálni práce. Vyd. 1. Hradec Králové: Gaudeamus. Jandourek J. (2007).Sociologický slovník. Vyd. 2. Praha: Portál.

Janebová R. (2010). Dilemata mezi právem a etikou aneb právo nezbavuje odpovédnosti. In M. Kappl, M. Smutek, Z. Truhlárová, (eds.) Etika sociálni práce. Hradec Králové: Gaudeamus.

Janebová R. (2012) Sebevýzkum jako cesta k dekonstrukci př́běbu rozhodování sociálni pracovnice. In Z. Truhlářová, K. Levická, (eds.) Od Teorie k praxi, od praxe k teorii. Vyd. 1. Hradec Králové: Gaudeamus. 
Kappl M. (2010). Možnosti uplatñováni Laanovy etiky diskursu v praxi priznivci radikálně konstruktivistických prìstupio. In M. Smutek, W.F Seibel, Z. Truhlářová (eds.) Etika sociální práce, Vyd. 1. Hradec Králové: Gaudeamus.

Kappl M. (2012). Od konstruktivistické teorie ke konstruktivistické praxi. In Z. Truhlářová, K. Levická, (eds.) Od teorie $k$ praxi, od praxe $k$ teorii. Vyd. 1. Hradec Králové: Gaudeamus.

Kasanová A. (2008). Sociálnezabezpečenieextrémne chudobných. In R. Janebová, M. Kappl, M. Smutek, (eds.) Sociálni práce mezi pomoci a kontrolou. Vyd. 1. Hradec Králové: Gaudeamus.

Kopřiva K. (2013). Lidský vztah jako soućást profese. Vyd. 7. Praha: Portál.

Kříčková L. (2011). Vsedni dilemata sociálních pracovnikiu v azylovém domé pro matky s dètmi. Brno: Masarykova Univerzita. Diplomová práce.

Květenská D. (2008). Moc a pomoc v pomáhajicich profesích. In R. Janebová, M. Kappl, M. Smutek, (eds.) Sociálni práce mezi pomoci a kontrolou. Vyd. 1. Hradec Králové: Gaudeamus.

LaanGeert van der. (1998). Otázky legitimace sociální práce: (pomoc není zboží). Vyd. 1. Boskovice: Albert.

Lehoczká L. (2010). Premenyrómského etnika - Rómoviamedzitradíciami a súčasnostou - Rómoviaakoich poznáme i nepoznáme. In M. Smutek, W.F. Seibel, Z. Truhlárová, (eds.) Etika sociálni práce. Vyd. 1. Hradec Králové: Gaudeamus.

Macková M. (2013). Specifické aspekty poskytování zdravotnich služeb u dètí podle nového zákona o zdravotnich službách. In R. Janebová, (ed.) Spolupráce v sociálni práci. Vyd. 1. Hradec Králové: Gaudeamus.

Matoušek O. (2008).Slovník sociální práce. Vyd. 2. Praha: Portál.

Mojžíšová A., Urban D., Kajanová A. (2012). Existuji dilemata v sociální práci o kterých se nemluví? In Z. Truhlářová, K. Levická, (eds.) Od teorie $k$ praxi, od praxe k teorii. Vyd. 1. Hradec Králové: Gaudeamus.

Musil L. (2004).,,Ráda bych vám pomohla, ale... “In Dilemata práce s klienty v organizacich. Brno: Marek Zeman.

Musil L. (2006). Copingwith Dilemmas. Working Conditions and Interactions of Social Workers with their Clients. Stassfurt: ISIS.

Musil L., Nečasová M. (2008). Zvládáni nesourodých očekáváni a morálni orientace pracovnikio. In J. Šrajer, L. Musil, (eds.) Etické kontexty sociálni práce s rodinou. Albert: Olomučany.

Musi L. (2008). Zpuisoby zvládáni dilematu jednostrannosti a symetrie. In R. Janebová, M. Kappl, M. Smutek, (eds.) Sociálni práce mezi pomocí a kontrolou. Vyd. 1. Hradec Králové: Gaudeamus.

Navrátil P. (2001). Vybrané teorie sociální práce. In O. Matoušek, a kol. Základy sociálni práce. Praha: Portál. 
Navrátil P. (2001). Teorie a metody sociálni práce. Vyd. 1. Brno: Marek Zeman,

Nečasová A. (2001). Úvod do filozofie a etiky v sociální práci. Brno: Masarykova univerzita,

Nedělníčková D.(2008). Metodická príručka pro výkon terénni sociálni práce. Ostravská Univerzita.

Ondrejkovič P. (2010). Veda alebointervencia do sociálnejskutočnosti? In M. Smutek, W.F. Siebel, Z. Truhlářová, (eds.) Rizika sociální práce. Vyd. 1. Hradec Králové: Gaudeamus..

Selická D. (2010). Pomoc, podpora sociálního pracovníka pri znovuobnovení etických hodnot v rómskéjrodine. In M. Smutek, W.F. Seibel, Z. Truhlářová, Z. (eds.) Etika sociální práce. Vyd. 1. Hradec Králové: Gaudeamus.

Stachoň M. (2012). Môze to byt správne $v$ teórii, ale nehodi sa to preprax. In Z. Truhlářová, K. Levická, (eds.) Od teorie $k$ praxi, od praxe $k$ teorii. Vyd. 1. Hradec Králové: Gaudeamus.

Stachová V. (2012). Etická dilemata sociálni pracovniků prì práci s obèti domácího násilí. České Budějovice: Jihočeská Univerzita. Diplomová práce.

Sýkorová K. (2008). Základy sociologie, filosofie a etiky pro pomáhající profese. Vyd. 1. Liberec: Technická univerzita v Liberci.

Ševčíková S. (2008). Pomoc a kontrola v terapeuticky pojaté sociální práci. In R. Janebová, M. Kappl, M. Smutek, (eds.) Sociálni práce mezi pomoci a kontrolou. Vyd. 1. Hradec Králové: Gaudeamus.

Šotola R. (2012). Vztah školy a rodiny ze sociálnè vyloučené lokality - výzva pro sociálni práci. In Z. Truhlářová, K. Levická, (eds.) Od teorie $k$ praxi, od praxe $k$ teorii. Vyd. 1. Hradec Králové: Gaudeamus.

Šveřepa M. (2010). Prosazováni a obhajoba práv klientek sociálni práce. Príběh, který neni. In M. Smutek, W.F. Seibel, Z. Truhlářová (eds.) Etika sociální práce. Vyd. 1. Hradec Králové: Gaudeamus.

Úlehla I. (2005). Uméni pomáhat: učebnice metod sociální praxe. Vyd. 3., Praha: Sociologické nakladatelství SLON.

Vlachovičová-Mihalová A., Csámpai O. (2010). Rizikové dôsledkysúčasnýchkoncepcii a pristupov $k$ riešeniurómskej problematiky. In M. Smutek, W.F., Seibel, Z. Truhlářová, (eds.) Rizika sociálni práce. Vyd. 1. Hradec Králové: Gaudeamus. Vojtko T. (2008). Dilema normality v teorii a praxi pomáhajicích profesí. In R. Janebová, M. Kappl, M. Smutek, (eds.) Posuzováni životni situace v sociální práci. Vyd. 1. Hradec Králové: Gaudeamus. 


\title{
Dilemmas of social workers with regard to work with the Roma ethnic group
}

\begin{abstract}
In this paper we will first define the dilemmas and describe the process of their their formation. We will describe dilemmas in history through six ethical value and ethical orientations. We will outline the ethical problems of social workers as they are included in the Code of Ethics of the Society of Social Workers oft he Czech Republic. In the next part of we will deal with the dilemmas of contemporary social work. We will define eighteen dilemmas and statefore each of them how they may eventually be reflected in work with the Roma ethnic group. The author's personal experiences as well as the experiences of social workers will be presented. In this paper we suggest different options for dealing with dilemmas.
\end{abstract}

Keywords: dilemma, socia lwork, code of ethics, social worker, Roma ethnic group

\section{Dylematy pracowników socjalnych związane z pracą z romską grupą etniczną}

\section{Streszczenie}

W tym tekście w pierwszej kolejności zdefiniujemy dylematy oraz opiszemy proces ich powstawania. Skoncentrujemy się na opisie dylematów w historii za pośrednictwem sześciu wartości i kierunków etycznych. Zarysujemy dylematy etyczne oraz problemy pracowników socjalnych tak jak są ujęte w Kodeksie Etyki Pracowników Socjalnych Republiki Czeskiej. W części dalszej zajmiemy się dylematem współczesnej pracy socjalnej. Zdefiniujemy osiemnaście dylematów i podamy jak każdy z nich może rzutować na pracę z romską grupą etniczną. Przedstawione zostaną osobiste doświadczenia Autora jak i doświadczenia pracowników socjalnych. W tej pracy sugerujemy różne możliwości radzenia sobie z dylematami.

Słowa kluczowe: dylematy, praca socjalna, kodeks etyczny, pracownik socjalny, romska grupa etniczna. 